\title{
Variation in Content of Carotenoids and Vitamin C in Carrots
}

\author{
Jana MATĚJKOVÁ, Kristína PETŘÍKOVÁ \\ Faculty of Horticulture Lednice, Mendel University in Brno, Czech Republic; petrk@zf.mendelu.cz
}

\begin{abstract}
Carrots are the most popular and wide-spread of all root vegetables, and are the principal source of carotenoids in human diet. The purpose of this study was to examine differences between cultivars and the effect of storage regarding the carotenoid and vitamin $\mathrm{C}$ content in carrots. Six carrot cultivars were used in this study, ranging from early to late ones. Observed carotenoid content ranged from $60 \mathrm{mg} \mathrm{kg}^{-1}$ to $134 \mathrm{mg} \mathrm{kg}^{-1}$. Significantly higher levels of carotenoids were found in late and moderately late cultivars in comparison to early ones. Vitamin C content in these cultivars ranged from $54 \mathrm{mg} \mathrm{kg}^{-1}$ to $132 \mathrm{mg} \mathrm{kg}^{-1}$. Significantly higher contents of vitamin $\mathrm{C}$ were also found in the late cultivars. 30-day storage resulted in a significant reduction in vitamin C content, on average of $47 \%$. There was also a reduction in the carotenoids content, but to a lesser extent, on average of $11 \%$.
\end{abstract}

Keywords: nutritional value, carrots, cultivars, storage

\section{Introduction}

Carrot is a root vegetable, and is in demand throughout the whole year. The average carrot consumption in the Czech Republic in 2008 was $6.2 \mathrm{~kg}$ per person (Czech Rep., 2008). Carrots in general are one of the best sources of $\beta$-carotene in our diet, and provide $17 \%$ of the total $\beta$-carotene intake in human nutrition (Alasalvar et al., 2001). Carrots also contain a wide spectrum of other antioxidant substances, such as phenolic compounds, and also vitamin $\mathrm{C}$, which is one of the most important compounds to be found in vegetables.

There were reported differences between cultivars regarding the content of carotenoids (Alasalvar et al., 2001; Karkleliene et al., 2007; Vulsteke, 1996), and also vitamin C (Bratu et al., 2006; Lee and Kader, 2000; Pokluda, 2003). Vitamin $C$ in carrots ranges from $21 \mathrm{mg} \mathrm{kg}^{-1}$ (Pokluda, 2003) to $775 \mathrm{mg} \cdot \mathrm{kg}^{-1}$ (Lachman et al., 2000), and carotenoids from $50 \mathrm{mg} \mathrm{kg}^{-1}$ (Kopec, 1998) to 159 mg. $\mathrm{kg}^{-1}$ (Müller, 1997). Since carrots are important source of vitamin $\mathrm{C}$ and carotenoids in the human diet, it is appropriate to determine to what extent these compounds are lost during storage. Singh et al. (2001) mentioned vitamin $\mathrm{C}$ and carotenoid losses after storage, with higher losses for vitamin C. Favell (1998) noted a 15\% decrease of vitamin $\mathrm{C}$ after 14 days storage at $4^{\circ} \mathrm{C}$. The potential decrease of carotenoid levels after storage was also reported by Lee (1986).

The aim of this study was to determine the contents of vitamin $\mathrm{C}$ and carotenoids in 6 different carrot cultivars and to study the effect of a 30-day storage period on the contents of these compounds.

\section{Materials and methods}

Six carrot cultivars, ranging from early to late (Tab. 1), were grown during the years 2004 and 2005 in fields belonging to Mendel University at the Faculty of Horticulture in Lednice (GSP location 48 47'36.858' $\mathrm{N}$, $16^{\circ} 47^{\prime} 49.526^{\prime \prime E}$ ). Tab. 2 shows average temperatures and total rainfalls during the growing season in each year and long-term seasonal averages. The carrots seeds were sown directly into the plots in the middle of April. Soil analyses showed high levels of all soil nutrients except nitrogen. The nitrogen fertilization, as well as other agronomic practices were in accordance with standard recommendations for growing carrots (Malý and Petříková, 1998). The harvest was made by hand in agricultural terms, with the early cultivars being harvested in July and the late cultivars being harvested in September. Only the late cultivars 'Olympia', 'Tinga' and 'Nerac F1' were placed in

Tab. 1. Experimental cultivars

\begin{tabular}{|c|c|c|c|}
\hline Cultivar & Characteristics & Registration & Breeding \\
\hline 'Delicia' & very early cultivar & 1966 & Sempra Praha \\
\hline 'Kráska' & $\begin{array}{c}\text { semi-early, type } \\
\text { Berlicum }\end{array}$ & 1996 & $\begin{array}{c}\text { Ing. Jitka } \\
\text { Hrubešová }\end{array}$ \\
\hline $\begin{array}{l}\text { 'Stupická } \\
\text { k rychlení' }\end{array}$ & $\begin{array}{l}\text { early cultivar, } \\
\text { type Nantés }\end{array}$ & 1954 & Moravoseed \\
\hline 'Nerac F1' & $\begin{array}{l}\text { semi-late, } \\
\text { type Nantés }\end{array}$ & 1995 & Bejo Zaden \\
\hline 'Olympia' & late cultivar & 1973 & Seva-Flora \\
\hline 'Tinga' & $\begin{array}{l}\text { late cultivar, } \\
\text { type Flakkee }\end{array}$ & 1998 & Moravoseed \\
\hline
\end{tabular}

Note: Cultivars came from Czech Rep., 'Nerac F1' from Holland 
Tab. 2. Average monthly air temperatures $\left({ }^{\circ} \mathrm{C}\right)$ and rainfall totals $(\mathrm{mm})$ during the growing season in years 2004 and 2005 and the values of long-term seasonal

\begin{tabular}{|c|c|c|c|c|c|c|c|c|c|c|c|c|}
\hline \multirow{2}{*}{ Year } & \multicolumn{6}{|c|}{ Average air temperature $\left({ }^{\circ} \mathrm{C}\right)$} & \multicolumn{6}{|c|}{ Rainfall totals (mm) } \\
\hline & IV & $\mathrm{V}$ & VI & VII & VIII & IX & IV & $\mathrm{V}$ & VI & VII & VIII & IX \\
\hline 2004 & 11.5 & 13.7 & 17.6 & 19.7 & 20.3 & 14.8 & 16.2 & 27.7 & 99.4 & 58.9 & 31.6 & 44.0 \\
\hline 2005 & 11.2 & 15.7 & 18.4 & 20.2 & 18.4 & 16.0 & 47.1 & 77.1 & 51.2 & 101.5 & 87.2 & 22.1 \\
\hline $\begin{array}{c}\text { Long-term seasonal } \\
1961-1990\end{array}$ & 9.7 & 14.5 & 17.5 & 19.1 & 18.5 & 14.7 & 34.7 & 57.7 & 66.4 & 59.8 & 50.0 & 37.3 \\
\hline
\end{tabular}

storage, where they stayed for 30 days at a temperature of $2-3^{\circ} \mathrm{C}$, with $90 \%$ relative humidity.

The determinations of vitamin $\mathrm{C}$ and carotenoid contents in the carrots were carried out in the Department of Vegetable and Flower Production in Lednice, each determination being replicated three times. These observations were made immediately after harvest and again after 30-days of storage. Vitamin C was determined by HPLC, total carotenoid content by colorimetry (Holm,1954; Ecom Ltd., 1998). Analysis of variance and Tukey's test (Unistat 5.1) were employed in the statistical evaluation of the data.

\section{Results and discussion}

Vitamin C and carotenoid levels in six different cultivars of carrots, including both early and late cultivars, were examined in two successive years. The resulting values are shown in Tab. 3.

The highest values of vitamin $\mathrm{C}$ were observed in cv. 'Olympia' (132 $\mathrm{mg} \mathrm{kg}^{-1}$ ), the lowest vitamin C levels were found in cv. 'Stupická k rychlení' ( $54 \mathrm{mg} \mathrm{kg}^{-1}$ ). The average vitamin $\mathrm{C}$ level in the carrots was $84 \mathrm{mg} \mathrm{kg}^{-1}$. Statistical analysis showed significantly higher vitamin $\mathrm{C}$ in the late cultivars 'Olympia' and 'Tinga' compared to the early

Tab. 3. Average (mean \pm S.D.) vitamin $C$ and carotenoids content in carrot cultivars

\begin{tabular}{|c|c|c|c|c|c|c|}
\hline \multicolumn{7}{|c|}{2004} \\
\hline \multirow[b]{2}{*}{ Cultivar } & \multicolumn{4}{|c|}{ Compound (mg.kg $\left.{ }^{-1}\right)$} & \multicolumn{2}{|c|}{ Loss after storage (\%) } \\
\hline & Vitamin C & $\begin{array}{l}\text { Vitamin C } \\
\text { after storage }\end{array}$ & Carotenoids & $\begin{array}{l}\text { Carotenoids } \\
\text { after storage }\end{array}$ & Vitamin C & Carotenoids \\
\hline 'Delicia' & $61 \pm 16.96 \mathrm{a}$ & - & $84 \pm 9.33 \mathrm{a}$ & - & - & - \\
\hline 'Kráska' & $73 \pm 21.49 \mathrm{ab}$ & - & $95 \pm 33.00 \mathrm{ab}$ & - & - & - \\
\hline 'Stupickák rychlení' & $54 \pm 20.99 \mathrm{ab}$ & - & $92 \pm 9.47 \mathrm{a}$ & - & - & - \\
\hline 'Nerac F1' & $88 \pm 7.03 b$ & $47 \pm 8.68^{*}$ & $134 \pm 14.98 \mathrm{~b}$ & $123 \pm 13.30$ & 47 & 8 \\
\hline 'Olympia' & $132 \pm 32.65 \mathrm{c}$ & $43 \pm 12.68^{*}$ & $141 \pm 21.95 b$ & $120 \pm 49.58$ & 67 & 15 \\
\hline 'Tinga' & $100 \pm 31.52 \mathrm{abc}$ & $41 \pm 7.74^{*}$ & $114 \pm 12.32 \mathrm{~b}$ & $110 \pm 25.92$ & 59 & 4 \\
\hline Mean & 85 & & 110 & & 58 & 9 \\
\hline \multicolumn{7}{|c|}{2005} \\
\hline \multirow[b]{2}{*}{ Cultivar } & \multicolumn{4}{|c|}{ Compound (mg.kg-1) } & \multicolumn{2}{|c|}{ Loss after storage (\%) } \\
\hline & Vitamin C & $\begin{array}{l}\text { Vitamin C } \\
\text { after storage }\end{array}$ & Carotenoids & $\begin{array}{l}\text { Carotenoids } \\
\text { after storage }\end{array}$ & Vitamin C & Carotenoids \\
\hline 'Delicia' & $62 \pm 9.13 \mathrm{a}$ & - & $61 \pm 1.36 \mathrm{a}$ & - & - & - \\
\hline 'Kráska' & $88 \pm 8.64 b$ & - & $77 \pm 5.40 \mathrm{a}$ & - & - & - \\
\hline 'Stupická k rychlení' & $61 \pm 5.60 \mathrm{a}$ & - & $60 \pm 14.13 \mathrm{a}$ & - & - & - \\
\hline 'Nerac F1' & $72 \pm 5.04 b$ & $51 \pm 6.94^{*}$ & $127 \pm 9.53 b$ & $104 \pm 9.95^{*}$ & 29 & 18 \\
\hline 'Olympia' & $103 \pm 13.77 c$ & $63 \pm 6.05^{*}$ & $97 \pm 8.72 \mathrm{c}$ & $91 \pm 9.83$ & 39 & 6 \\
\hline 'Tinga' & $117 \pm 14.67 \mathrm{c}$ & $70 \pm 9.52^{*}$ & $105 \pm 13.32 \mathrm{c}$ & $88 \pm 6.53^{*}$ & 40 & 16 \\
\hline Mean & 84 & & 88 & & 36 & 13 \\
\hline
\end{tabular}

Note: Different letters express significant differences between cultivars for $\mathrm{P} \leq 0,05 ;{ }^{*}$ Significant differences after storage for $\mathrm{P} \leq 0,05$.; Levels of vitamin $\mathrm{C}$ varied significantly between the two years in which this study was made. 
90

cultivars 'Delicia', 'Kráska', 'Stupická k rychlení' and the medium-late cultivar 'Nerac F1'.

After 30 days of storage there was an average decrease in vitamin C of $47 \%$. Statistical analysis showed a significant difference in vitamin $\mathrm{C}$ levels in carrots before and after storage (Tab. 3). The losses of vitamin $\mathrm{C}$ ranged from $29 \%$ (cv. 'Nerac F1') to 67\% (cv. 'Olympia').

The average total carotenoid content in the carrots, measured immediately after harvest, was $98 \mathrm{mg} \mathrm{kg}^{-1}$. The highest value for carotenoids was observed in the late $\mathrm{cv}$. 'Olympia' in $2004\left(141 \mathrm{mg} \mathrm{kg}^{-1}\right)$, and the lowest value was observed in 2005 in the early cv. 'Delicia' (61 mg $\mathrm{kg}^{-1}$ ) (Tab. 3). In 2005, lower values of carotenoids were observed in all cultivars. Statistical analysis showed significantly higher levels of carotenoids in the late cvs. 'Olympia' and 'Tinga' and medium-late 'Nerac F1', compared to the early cvs. 'Delicia', 'Kráska' and 'Stupická k rychlení' (Tab. 3). The early carrot cultivars contained on average $76 \mathrm{mg} \cdot \mathrm{kg}^{-1}$ of carotenoids, whereas the late cultivars contained on average $120 \mathrm{mg} \mathrm{kg}^{-1}$ of carotenoids.

After 30 days of storage the late carrot cultivars showed a decrease in total carotenoids of about $11 \%$ on average, dropping to an average value of $106 \mathrm{mg} \mathrm{kg}^{-1}$. A significant difference in carotenoid content before and after storage was confirmed. The highest decrease of carotenoid content was noted in cv. 'Nerac F1' (18\%), the lowest losses were noted in cv. 'Tinga' (4\%).

Among the six early to late carrot cultivars used in this study, the late cultivars had higher levels of both vitamin C and also of carotenoids. In the case of vitamin $\mathrm{C}$, the range of observed values was very wide, reflecting the differences known to exist between the various cultivars (Singh et al., 2001; Iqbal et al., 2006). The values for carotenoids were in line with previously published observations (Kopec, 1998; Gebczynski, 2006).

Variations in the vitamin $\mathrm{C}$ content of different carrot cultivars has been observed before (Alasalvar et al., 2001; Lee and Kader, 2000). Significantly higher levels of vitamin C in the late crs. 'Olympia' and 'Tinga' were reported by Pokluda (2003), although Bratu et al. (2006) reported higher levels of vitamin C in early carrot cultivars $\left(75 \mathrm{mg} \cdot \mathrm{kg}^{-1}\right)$ compared to late cultivars (31-46 $\left.\mathrm{mg} \cdot \mathrm{kg}^{-1}\right)$. Similarly, varietal differences in carotenoid content were also confirmed, in line with many similar previous observations (Alasalvar et al., 2001; Karkleliene et al., 2007; Vulsteke, 1996). Analyses showed differences in the carotenoid content between early and late cultivars, as did Müller (1997), who observed higher carotenoid content in older and bigger carrot roots $\left(159 \mathrm{mg} \cdot \mathrm{kg}^{-1}\right)$ in comparison with younger carrots $\left(95 \mathrm{mg} \cdot \mathrm{kg}^{-1}\right)$. Fritz and Weichmann (1979) also observed higher $\beta$-carotene content in late-harvested carrots.

Lower carotenoid values in the year 2005 were apparently caused by lower temperatures during the growing season-temperatures were on average $2^{\circ} \mathrm{C}$ lower in August 2005 in comparison with August 2004, and this could be determinant for the final carotenoid levels in carrots, which were harvested in September. Similar effects of ambient temperature on carotenoid levels in carrots have been noted before Rosenfeld et al. (1999), Alasalvar et al. (2001).

Carrots stored for 30 days at a temperature of $2-3^{\circ} \mathrm{C}$ and $90 \%$ relative humidity showed a $47 \%$ decrease in vitamin C and an 11\% decrease in carotenoids. Similar results were reported by Singh et al. (2001), who observed a 49\% decrease in vitamin C (from $146 \mathrm{mg} \mathrm{kg}^{-1}$ to $75 \mathrm{mg} \mathrm{kg}^{-1}$ ) and an $11 \%$ decrease in $\beta$-carotene after 30 days of storage, so it would appear that in comparison with $\beta$-carotene, the losses of vitamin $C$ in stored carrots are always considerably higher. Favell (1998) reported an $85 \%$ decrease in the initial vitamin $\mathrm{C}$ content in carrots stored at $4^{\circ} \mathrm{C}$ for 14 days.

The choice of cultivar and storage are very important factors affecting vitamin $\mathrm{C}$ and carotenoid levels in carrots. In comparison with vitamin $\mathrm{C}$, carotenoids are less sensitive to losses in storage, a fact confirmed in this study.

\section{Conclusions}

This work confirms the existence of important differences between carrot cultivars regarding vitamin $C$ and carotenoid contents. Higher amounts of these nutritionally important compounds were observed in late cultivars compared to early cultivars. After 30 days of storage the levels of both compounds were significantly lower. Higher losses were noted for vitamin C.

\section{References}

Alasalvar, C., J. M. Grigor, D. Zhang, P. C. Quantick and F. Shahidi (2001). Comparison of volatiles, phenolics, sugars, antioxidant vitamins and sensory quality of different colored carrot varieties. J. Agric.Food Chem. 49(3):410-1416.

Bratu, M., D. Avram and L. Buruleanu (2006). The minerals and vitamin content variation from different vegetables raw materials. The applied scientific research in colleges of Lithuania 4(3):86-88.

Czech Republic. Ministry of Agriculture (2008). Situation and Forecast Report. Vegetables. Min. Agric. Czech Republic. "(in Czech)"

Ecom Ltd. (1998). Determination of vitamin C by RP-HPLC, 2 pp.

Favell, D. J. (1998). A comparison of the vitamin C content of fresh and frozen vegetables. Food Chem. 62(1):59-64.

Fritz, D. and J. Weichmann (1979). Influence of the harvesting date of carrots on quality and quality preservation. Acta Hort. 93:91-100.

Gebczynski, P. (2006). Content of selected antioxidative compounds in raw carrot and in frozen product prepared for consumption. Food Sci. Technol. 9(3):8.

Holm, F. (1954). Chlorophyll mutations in barley. Acta Agric. 
Scand. (4):457-471

Iqbal, M. P., S. F. Kazim and N. Mehboobali (2006). Ascorbic acid contents of pakistani fruits and vegetables. Pakistan J. Pharmac. Sci. 19(4):282-285.

Karkleliene, R., D. Juškevičiene and P. Viškelis (2007). Productivity and quality of carrot (Daucus sativus Röhl.) and onion (Allium cepa L.) cultivars and hybrids. Scientific. Works of the Lithuanian Inst. of Hort. and Lithuanian Univ. of Agriculture 26(3):208-216.

Kopec, K. (1998). Nutritonal Values Tables of Fruits and Vegetables. "(in Czech)" Press Prague, Institute of Agricultural and Food Production Informations.

Lachman, J., M. Orsák and V. Pivec (2000). Antioxidants Contents and Composition in Some Vegetables and Their Role in Human Nutrition. Hort. Sci. 27(2):65-78.

Lee, C. Y. (1986). Changes in carotenoid content of carrots during growth and post-harvest storage. Food Chem. 20(4):285-293.

Lee, S. K., A. A. Kader (2000). Preharvest and postharvest factors influencing vitamin $\mathrm{C}$ content of horticultural crops. Postharvest Biology and Technology. 20:207-220.

Malý, I. and K. Petř́ková (1998). Elements of Root Vegetables Growing. Press Prague, Institute of Training and Education of Min. Agric. Czech Rep (in Czech).

Mozafar, A. (1994). Plant vitamins: agronomic, physiological, and nutritional aspects. USA: CRC Press, Inc.

Müller, H. (1997). Determination of the carotenoid content in selected vegetables and fruit by HPLC and photodiode array detection. European Food Res. and Technol. 204:88-94.
Pavlek, P., R. Heneberg and D. Horgas (1975). Influence of cultivars and of climatic conditions on yield and quality of carrot. Acta Hort. 52:239-252.

Pokluda, R. (2003). Nutritional Quality of Selected Sorts of Vegetables. Mendel University of Agriculture and Forestry Brno, Horticultural Faculty Lednice, Inaugural Diss. 1-167 (in Czech).

Rosenfeld, H. J., R.T. Samuelsen and P. Lea (1999). The effect of temperature on sensory quality, chemical composition and growth of carrots (Daucus carota L.). III. Different diurnal temperature amplitudes. J. Hort. Sci. Biotechnol. 74:196202.

Rosenfeld, H. J., R. T. Samuelsen, M. Bodson and M. N. J. Verhoyen (2000). The effect of soil-relationships and temperature on sensory and chemical quality parameters of carrots (Daucus carota L.). Proc. of the XXV Internat. Hort. Congress.1:123-132.

Singh, G., A. Kawatra and S. Sehnal (2001). Nutritional composition of selected green leafy vegetables, herbs and carrots. Plant Foods for Human Nutrit. 56(4):359-364.

Vulsteke, G. (1996). Einfluss von Sorte und Erntezeit auf die chemische Zusammensetzung von Moehren Typ "Amsterdam Forcing“. Die Industrielle Obst- und Gemüseverwertung. 81(4):129-134. 